\title{
Kerk - Kultuur - Volk - Owerheid
}

W A Dreyer

Nederduitsch Hervormde Gemeente Horison

Tydelik-deeltydse dosent: Departement Kerkgeskiedenis

en Kerkreg (Afd A)

Universiteit van Pretoria

\begin{abstract}
Church - Culture - People - Government

Since 1994 the Republic of South Africa has undergone profound political and cultural changes. The churches in South Africa (including the Nederduitsch Hervormde Kerk van Afrika as an Afrikaans-orientated church) need to evaluate the situation and come to a theological understanding of their relationship with the culture, people and government of South Africa. This article examines the relationship between church, culture, people and government from an historical, theological, philosophical and practical perspective.
\end{abstract}

\section{INLEIDING}

Die 64e Algemene Kerkvergadering (AKV 1995) van die Nederduitsch Hervormde Kerk van Afrika (NHKA) het vanaf 26 Junie 1995 in Pretoria vergader. Die AKV 1995 het onder andere oor die Hervormde Kerk se verhouding met die owerheid, die voortgang van die Hervormde Kerk se barmhartigheidsdiens in die nuwe Suid-Afrika, volkskerk, landskerk, multikulturele gemeentes, Christelik-volkseie skole, lidmaatskap van die Hervormde Kerk, sending en bedieningstrukture in die huidige omstandighede besin (AKV 1995:3, 10, 11, 37, 52, 54, 55-58, 145, 146). Deur net vlugtig na die inhoudsopgawe van die Besluitebundel van die AKV 1995 te kyk, is dit duidelik dat die Hervormde Kerk tans ernstig worstel met die veranderinge wat in die Republiek van Suid-Afrika aan die gang is.

Die NHKA het nie 'n keuse oor hoe die strukture van die owerheid, politiek of samelewing lyk waarin die kerk se taak volvoer moet word nie (Van der Westhuizen 1996:150). Die kerk moet egter in elke gegewe konteks getuig van Jesus Christus, die Here. Dit is die kerk se roeping waaraan nie ontkom kan word nie. Die geskiedenis leer ons dat die kerk se antwoord op nuwe politieke omstandighede nie altyd dieselfde gebly het nie. Daar is telkens eietydse antwoorde aangebied op eietydse vrae. Sekere 
basiese beginsels het onveranderd gebly, maar dit moet nut toegepas word wanneer die omstandighede verander. Dit moet die NHKA ook nou doen, veral omdat die situasie waarin die kerk verkeer, kompleks van aard is.

Wanneer die NHKA die vraag na die burgerlike owerheid vra en die verhouding met die volk en kultuur beantwoord, kan dit alleen gedoen word deur biddend te luister na die Woord van God (Mans 1962:90). Die Skrif bly immers ons maatstaf vir die beoordeling van sake. Die Skrif bied egter nie pasklaar antwoorde vir elke tyd en situasie nie. Die Skrif moet vir die eie tyd herinterpreteer word. Dit kan ons alleen doen deur nie net na die Skrif te luister nie, maar ook na medegelowiges wat in húlle omstandighede oor die Skrif nagedink en geworstel het om antwoorde op die politieke omstandighede van hulle tyd te vind.

Wanneer die NHKA hierdie vrae vra, doen die kerk dit met die wete dat die lidmate tussen die koms en die wederkoms van Jesus Christus leef; dat in Jesus Christus die koninkryk van God naby gekom het. Die kerk bely dat die burgerskap van die kerk

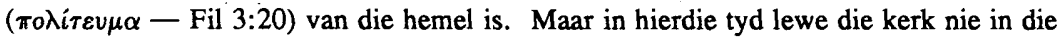
hemel nie, maar op die aarde (Barth 1954:78). Die kerk weet ook dat die vrede, vryheid en menslikheid wat die owerheid moet verseker, net uitwendig, voorlopig en provisioneel van aard is (Barth 1954:16). Ten spyte daarvan kan die kerk nie aan die wêreld en die politiek onttrek word nie (Barth 1954:82). Hoewel die kerk nie van hierdie wêreld is nie, is dit geroepe om met die kragtige Woord van God die wêreld in te tree en te getuig van Jesus Christus, die Verlosser en Heer. As die kerk maar nat met die kerk besig kan bly, verstom die stem van God die wêreld.

\section{Historiese oorsig}

\subsection{Antieke beskawings}

'n Vlugtige oorsig oor die geskiedenis laat mens besef dat godsdiens, kultuur en staatswese vir duisende jare in alle beskawings verweef was. Die Sumeriese beskawing van Mesopotamië kan as voorbeeld di.n. Die beskawing het 'n monargie in 2700 v C gehad. Inligting oor dié monargie word verkry uit die sogenaamde 'koningslyste', waarin vermeld word dat die monargie se oorsprong by die gode in die hemel lê. Ook die Babiloniese en Assiriese konings het die Sumeriese tradisie voortgesit en vasgehou aan die goddelike oorsprong van die monargie (Fiore 1965:81; Caldwell 1966:38). In die Epos van Etana lees ons: 
Daardie tyd is geen tiara gedra nie, en die septer, tulband, tiara en staf is voor Anu in die hemel neergesit. Daar was nooit 'n koninklike regering oor haar volk nie. Toe het die koningskap uit die hemel gekom ....

(vertaal uit Saggs 1962:359)

Die volle spektrum van sosiale en kulturele instellings asook politieke en ekonomiese aktiwiteite, is deur die Sumeriese godsdiens beïnvloed. Die koning is volledig vergoddelik en het 'n buitengewoon belangrike rol in die tempeldiens gespeel. Onder andere het hy in die tempel geslaap om deur middel van drome met die gode te kommunikeer (Caldwell 1966:46). Verder was daar Sumeriese gode wat spesifieke stede en stamme beskerm het: Ea was die god van Eridu, Enlil van Nipur, Anu van Uruk en Utu van Sippar. Hierdie gode, so is geglo, het hulle stede op 'n besondere wyse beskerm. Marduk en Enlil is gudurende verskillende tye as die nasionale gode beskou :iore 1965:51).

Die Egiptiese mitologie vertel dat Re, die songod, die hele Egipte besit en regeer het. Naderhand het hy moeg geword om die aarde te regeer en het hy sy seun, Horus, agtergelaat om oor Egipte te regeer. Hyself het na die hemel teruggekeer (Caldwell 1966:73). Sedert 2500 v C, met die aanbreek van die oud-Egiptiese koninkryk, is die farao self as 'n god beskou. Elke farao is beskou as 'n seun van Re, omdat geglo is dat Re die koningin besoek en by haar 'n kind verwek het. Die farao is dus as volledig goddelik beskou. Elke aspek van die Egiptiese samelewing, kultuur en veral politieke gebeure, is deur godsdienstige oorwegings gelei.

Die Hellenisties/Griekse filosofie het ook na 'n godsdienstige onderbou van die samelewing, die wet en die staat gesoek. Die Griekse geskiedenis het ongeveer 2000 jaar voor Christus begin (Dreyer 1987:28) toe die Ioniërs Griekeland en die omringende eilande begin beset het. Op daardie stadium het daar reeds 'n goed ontwikkelde beskawing bestaan, naamlik die Minoïese beskawing. Die gevolg was dat toe die Sofiste teen die vyfde eeu voor Christus begin optree het, hulle 'n kultuurgeskiedenis van 1500 jaar gehad het waanuit hulle kon put.

Dit was veral die filosowe Sokrates (circa 399 v C), Plato (circa 347 v C), en Aristoteles (circa 323 v C), wat op 'n besondere wyse oor die staat en die samelewing nagedink het. Hulle het 'n enorme invloed op die Westerse kultuur uitgeoefen. Aristoteles het byvoorbeeld die mens beskou as 'n 'gemeenskapsdier', omdat die mens 'n medemens op alle vlakke van bestaan nodig het. Op natuurlike vlak is mense van mekaar afhanklik vir hulle voortbestaan (prokreasie, beskerming en voedselproduksie). Ook op geestelike vlak (beplanning, samewerking en die bevordering van die gemeenskap) is hulle van mekaar afhanklik. 'n Kenmerk van hierdie gemeenskap is dat mense onderling vaste bande skep en dit bestendig, veral deur politieke strukture (Murray 1987:11). 


\subsection{Israel}

Soos met ander antieke kulture, is die Ou-Testamentiese volk Israel se kultuur en politieke instellings wesenlik deur hulle godsdiens/geloof bepaal (Edelkoort 1957:5). Die verhouding tussen godsdiens en kultuur het deur die loop van eeue verander, maar het deurlopend wedersydse invloed op mekaar uitgeoefen. Selfs vandag oefen dit 'n bepaalde invloed uit, onder andere op Afrikaners se nadenke oor hulle eie volk en politiek (Breytenbach 1996:12). Wat Israel so uniek gemaak het, is die feit dat God Homself juis deur en in hierdie volk geopenbaar het. Die Ou Testament verkondig aan ons dat God Homself binne 'n bepaalde kultuur, binne bepaalde denk- en taalvorme, geopenbaar het. God openbaar Homself aan mense binne hulle leefwêreld. Dit beteken nie dat die godsdiens maar net ' $n$ hemelse goedkeuring aan die menslike kultuur verleen het nie - inteendeel, juis omdat die kultuur uit die sondige mens voortkom, het die godsdiens dikwels korrigerend teenoor die kultuur opgetree.

Die gedagte dat daar ' $n$ enkele aspek van menslike lewe en kultuur kan bestaan wat met godsdiens en geloof niks te make het nie, is iets wat uit die Westerse denktradisie na vore gekom het. In die antieke kulture, en ook in die Ou Testament, is dit nie teenwoordig nie. In die Ou Testament (veral Deuteronomium) word die totale menslike bestaan gereël aan die hand van godsdienstige verordeninge en wette. Nie net die Tien Gebooie nie, maar talle ander wette het die politiek, samelewing en kultuur van die Israeliete bepaal. Godsdiens het bepaal wat en hoe hulle geëet het, wat hulle aangetrek het, hoe hulle getrou en begrafnis gehou het, hoe hulle hulle kinders opgevoed het, hoe die Israeliet die grond bewerk het, geld geleen het en so meer. Geen enkele fasset van die kultuur of samelewing is aan willekeur of toeval oorgelaat nie. Veral die koningskap en politieke instellings van Israel was grotendeels deur die godsdiens bepaal. Die koning was ook 'n priester, wat sekere priesterlike funksies in die tempel uitgevoer het (Deist 1975:35).

As gevolg van Israel se kontak met omringende kulture en godsdienste, het daar ook verval in hulle godsdiens en kultuur ingetree. Die profete het in hulle verkondiging dit duidelik uitgewys. Die profete het krities gestaan teenoor die feit dat Israel deur ander godsdienste en kulture verlei is om van God afvallig te raak. Juis omdat kultuur en godsdiens so nou verweef was in die antieke beskawings, het oorheersing deur 'n vreemde moondheid ook godsdienstige implikasies ingehou. Wanneer die koning met 'n vrou uit 'n vreemde volk en kultuur getrou het, het hulle dikwels begin om die godsdiens van daardie volk na te volg (vgl koning Agab in 1 Kon 16:31vv).

\subsection{Die vroeë kerk}

Uit die geskiedenis van die vroegste Christelike kerk word onder andere twee dinge duidelik: 
Eerstens: Die verhouding tussen kerk en owerheid is een van oneindige afstand

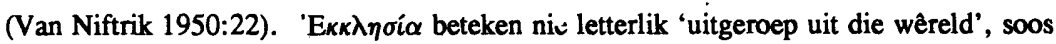
dit altyd etimologies verklaar word nie (Louw \& Nida 1988:126). Tog is dit so dat in die algemene Griekse omgangstaal $\dot{\varepsilon} \kappa \kappa \lambda \eta \sigma i \alpha$ 'n aanduiding van 'n bepaalde gemeenskap of groep teenoor ' $n$ ander gemeenskap of groep was, soos een stad teenoor ' $n$ ander stad. Wanneer die gelowiges van die vroeë kerk hulleself è $k к \lambda \eta \sigma i \alpha$ noem, grens hulle hulle daarmee af van ander $\dot{\varepsilon} \kappa \kappa \lambda \eta \sigma i \alpha$. Die eerste Christene het geweet dat die koninkryk waarvan hulle deel was, iets anders was as die koninkryk van hierdie wêreld. Immers, Jesus het self vir Pontius Pilatus geantwoord: My koninkryk is nie van hierdie wêreld nie.

Die oùdste gemeente het geweet dat hierdie wêreld verbygaan en hulle het hunkerend gebid: Kom Here, ja kom gou! Die eerste Christene het eerder 'n marteldood of die gevangenis verwag as een of ander politieke aanstelling. Hulle het die owerheid gesien as die vyand van die Christendom, as die dier, die antichris (Op 13). Hulle het vreemdelinge en bywoners geword in hulle eie vaderland (1 Pet 2:11). Hulle was altyd oppad na hulle eintlike vaderland (Heb 11). In hierdie eskatalogiese denke van die vroegste kerk was iets soos die politieke taak van die Christen nie ter sake nie. Daar was 'n gevoel van vreemdheid teenoor die owerheid. Hierdie vreemdheid teenoor die owerheid het vir etlike eeue voortgeduur. In die brief aan Diognetos $(2 \mathrm{e} / 3 \mathrm{e}$ eeu) lees ons: Christene woon in hulle vaderland, maar slegs as bywoners. Hulle doen aan alles mee as burgers en verduur alles as vreemdelinge. Elke vreemde land is vir hulle ' $n$ vaderland en elke vaderland 'n vreemdelingskap (Apostoliese Vaders II:359).

Tweedens: Die evangelie van Jesus Christus is onherroeplik van politieke belang (Van Niftrik 1950:25). Hoe het dit gebeur dat die Romeinse Ryk wat ten opsigte van die verskillende godsdienste binne die grense van die Ryk buitengewoon verdraagsaam was, die Christene so bitterlik vervolg het? Al die volke wat die Romeine oorwin het, se gode het ' $n$ nis in hulle pantheon gekry. As Christus maar net een so ' $n$ nis beklee het, sou daar geen probleem gewees het nie. Jesus Christus laat Hom egter nie in ' $n$ nis tussen ander gode wegsteek nie. Hy is die Een aan wie alle mag op hemel en aarde gegee is (Matt 28:18). Dit het politieke konsekwensies, want daarmee word Christus se soewereine mag geproklameer. Jesus is in die Nuwe Testament onder andere die Kurios, terwyl daar op die troon in Rome ook 'n kurios sit. Jesus is die Koning van die konings en die Here van die heersers (Op 19:16). Daarmee word geproklameer dat Jesus nie net oor die koninkryk van God regeer nie, maar inderdaad oor die ganse skepping - ook oor die owerhede van hierdie wêreld. Die mens wat dit erken, staan eintlik midde in die politiek. 
Dit sou ' $n$ verenging van die Bybelse kerugma wees, indien ons sou meen dat die evangelie net met die siel te doen het en niks met die liggaam van die mens nie; net met die hemel en niks met die aarde nie. Die dualisme van liggaam en siel deug nie, ook nie 'n dualisme van kerk en wêreld, hemel en aarde nie. Die Heidelbergse Kategismus (Vraag 1) sê tereg dat die gelowige met liggaam en siel aan Christus behoort. Jesus Christus het ook liggaamlik uit die dood opgestaan, om die liggaam en siel van gelowiges van die verderf te red. As ons die liggaamlikheid loslaat, verval ons in 'n spiritualisme, ' $n$ idealisme en piëtisme.

\subsection{Aurelius Augustinus}

Aurelius Augustinus het tussen 354-430 n C geleef. Hy word Doctor Charitatis genoem omdat hy die politiek in terme van die Goddelike liefde uiteengesit het (Versfeld 1987:118). Hy was biskop van die Rooms-Katolieke kerk. Hy het meer as enigiemand anders daartoe bygedra dat die klassieke kultuur en Christelike geloof saamgesmelt het. Grootliks op grond van hierdie samesmelting, het die Westerse beskawing vorm en gestalte gekry. Augustinus het geweet dat geen politieke bestel vir ewig duur nie, want hy het die ineenstorting van Rome en die Romeinse Ryk beleef - iets wat vir eeue as totaal onmoontlik beskou is. Die politieke realiteit waarbinne hy gewerk het, was dat die owerhede van hierdie wêreld kom en gaan. Dit, bo en behalwe die Heilige Skrif, het sy denke oor die owerheid wesenlik bepaal.

Augustinus onderskei baie skerp tussen die eskatalogiese civitas Dei en die civitas terrena, die koninkryk van God en die aardse koninkryk. Hierdie twee ryke staan teenoor mekaar, in 'n verhouding van vyandskap. Die aardse koninkryk is nietig en verganklik (soos die Romeinse Ryk). Die aardse koninkryk is tegelykertyd die civitas diaboli, die ryk van die duiwel. Augustinus leer verder dat die mens of burger is van die een ryk of van die ander ryk. Hierdie skerp onderskeiding tussen die geestelike en die zardse werklikhede is te wyte aan sy Neo-Platoniese denke wat 'n skerp onderskeid tussen stof en gees gehandhaaf het.

Die civitas terrena se bestaan is volgens Augustinus net geregverdig as dit aan twee vereistes voldoen, naamlik as dit oor 'n volk regeer en as dit in regverdigheid oor die volk regeer. Sonder 'n volk kan daar geen owerheid wees nie. Sonder regverdigheid/geregtigheid is daar geen samelewing nie. Dan is die owerheid bloot 'n magnum latrocinium - 'n groot rowersbende (Mans 1962:95). Augustinus se bekende uitspraak in dié verband is: Wat is koninkryke sonder regverdigheid anders as groot rowerye (De civitate Dei IV.4)? 
Volgens Augustinus is regverdigheid (iustitia) die behoud van 'n samelewing. Daarom vind ons by Augustinus geen slaafse gehoorsaamheid aan die owerheid nie. Inteendeel, sy negatiewe waardering van die aardse owerheid lei hom daartoe om te sê dat lex iniustitia non est lex - 'n onregverdige wet is geen wet nie. Dit is daarom nie bindend op die gewete nie. Dit is ' $\mathrm{n}$ gedagte wat ons reeds by Sokrates en Plato vind. Hierin lê die moontlikheid van verset teen die owerheid opgesluit. Vir Augustinus is regverdigheid die wese van die staat, en die wese van regverdigheid is te vind in die Goddelike en Christelike liefde (amor Dei). Dit is die gedagte van Romeine 13:8: Wees aan niemand iets verskuldig nie, behalwe om mekaar lief te he;; want hy wat 'n ander liefhet, het die wet vervul. Die probleem is egter dat die aardse owerhede baie selde hieraan voldoen.

\subsection{Middeleeue}

Die Middeleeue word gekenmerk deur die feit dat die kerk die dominante faktor in die samelewing, kultuur en politiek was. In baie gebiede was die kerk die owerheid en die regbank. Sondag het die biskop die sakramente bedien aan lidmate van die kerk en Maandag kon hy dieselfde lidmaat tronktoe stuur of ter dood veroordeel. Daar was, soos in die antieke kulture, nog geen skeiding tussen kerk, kultuur, volk, samelewing en owerheid nie. Dit het alles saam 'n corpus christianum gevorm. Die ligaam van Christus (1 Kor 12) was nie net die kerk nie, maar die totale samelewing. Dit is duidelik dat die corpus christianum nie in die eerste plek 'n teorie was nie, maar 'n vanselfsprekende bestaanswyse.

Die basiese uitgangspunt van die kerk in die Middeleeue was dat alles onder die regnum Christi staan, en dat die totale wêreld en samelewing verchristelik moes word (Botha 1996:18). Die respublica christiana en die ecclesia het sinoniem geword. Die probleem was egter dat in plek daarvan dat alles onder die heerskappy van Christus gekom het, alles onder die heerskappy van die pous beland het (papisme). Tog is dit so dat die teokratiese denke baie sentraal in die Roomse teologie gestaan het. Thomas Aquinas skryf in sy traktaat De Regno dat die beste regering die regering is wat in gehoorsaamheid voor Christus buig en volgens die wil van God regeer (vgl Villa-Vincencio 1986:24).

Die corpus christianum het geweldig negatief ingewerk op die kerk. Dit het die kerk laat verval en verwêreldlik. Die kerk het opgegaan in die samelewing. Hierteen het die Reformatore skerp kritiek uitgespreek - maar die basiese gedagte van die teokrasie, van die heerskappy van Christus oor die kerk en die skepping, het by hulle behoue gebly. 


\subsection{Martin Luther}

Luther het met sy onderskeiding tussen die geestelike en wêreldse regimente aangesluit by Augustinus. Dit gaan nie vir hom om ' $n$ verdeling van lewensgebiede, ' $n$ onderskeid tussen mense of die sosiologiese ordening van groothede soos kerk en staat nie, maar om die beskrywing van God se dubbele handeling met die skepping wat in sonde verval het (Kooiman 1957:1107). Hierdie gedagtegang van Luther kan alleen verstaan word teen die agtergrond van sy teosentriese denke en sy skeppingsteologie.

Omdat Luther die klem op die handelinge van God plaas, praat hy eerder van twee regimente as van twee ryke. Daarmee bedoel hy dat God op twee maniere oor die skepping regeer: Hy regeer regstreeks deur die geestelike regiment, dit is die verkondiging van die Woord en van die evangelie van genade. Hierdie regeerwyse is van toepassing op die kinders van Adam wat tot ware geloof in Jesus Christus gekom het. Wie die evangelie hoor en glo, is 'n nuwe mens en het eintlik nie die owerheid nodig nie (Luther [1523] 1955:146). Tweedens regeer God indirek deur die wêreldse regiment (deur die owerhede) wat hy daargestel het om sy skepping te beskerm teen die chaotiese magte van die bose. Hier vind die regering nie deur die evangelie plaas nie, maar deur die wet. Hierdie regering is in die eerste plek bedoel vir die kinders van Adam wat nie in Christus glo of God dien nie (Luther [1523] 1955:147). Luther onderskei dus ook in sy beskouing van die verhouding tussen kerk en owerheid tussen wet en evangelie.

Luther beskou nie die wêreld as twee gebiede, soos Augustinus nie. Die męns is onderworpe aan beide regimente, omdat God beide ingestel het. Die geestelike regiment is by Luther ook geen verinnerliking van die geloof nie, maar dit strek uit oor alle gemeenskapsordeninge. Ein Christ muss zwei Personen auf Erden tragen, Christperson und Weltperson. Die Christen moet in hierdie wêreld as 'n Christusmens en ook as 'n aardse mens leef. Die Christusmens leef onder die regiment van die Woord as geregverdigde sondaar voor die aangesig van God (coram Deo). As wêreldmens leef hy voor die aangesig van mense (coram hominibus) as vader, moeder, seun, dogter, as vors, regter, priester of dienskneg. Die Christen het dus 'n dubbele roeping: deur die evangelie geroep tot geloof, maar ook geroep om 'n taak in die wêreld uit te voer. Beide is ' $n$ roeping van God.

Luther het baie duidelik raakgesien dat hierdie wêreld deur God geskep is en dat dit nie deur God aan sy lot oorgelaat word nie. Ten spyte daarvan is hicrdie wêreld nie die laaste werklikheid nie. Dit kan nooit 'n paradys wees of word nie. Vir die Christenmens bly dit net 'n gastehuis, nie 'n tuiste nie. Die wêreld is die plek waar die evangelie verkondig moet word, maar daar is by Luther geen sprake (soos in die 
Roomse teologie) van die verchristeliking van die kultuur, volk, owerheid of die wêreld nie. Die kultuur hoef nie deur die genade geheilig te word nie (Kooiman 1957:1108). Die koninkryk van God is iets anders as Christelike strukture in kerk, volk, ekonomie, samelewing en owerheid. Die spanning tussen die twee ryke en twee regimente durf nooit laat vaar word nie. Elke Christen is 'n priester. Dit is elke Christen se roeping om die wêreld met die kragtige Woord van God te betree en die evangelie uit te dra. Luther lê dus besondere klem op die algemene priesterskap van die gelowige. Dit is van besondere betekenis vir elke aspek van gemeenskapslewe: Die huwelik, gesin, beroep, arbeid, ekonomie, openbare (politieke) ampte en die versorging van die armes.

\subsection{Johannes Calvyn}

Wanneer Johannes Calvyn in 1536 in Genève aankom, bestaan daar reeds 'n volkskerk volgens die model wat Zwingli in Zürich gevestig het. Genève was 'n selfstandige stadstaat wat regeer is volgens die eerste primitiewe republikeinse beginsels. Die owerheid het die volk en die kerk as identies beskou en daarom het dit in die praktyk gebeur dat die owerheid alle kerklike besluite geneem het, nadat die predikante aangehoor is (Dreyer 1995:15). Hierdie situasie was vir Calvyn onaanvaarbaar en gee aanleiding daartoe dat hy, soos die ander predikante van Genève, in 1538 uit Genève verban word. Die afleiding kan gemaak word dat Calvyn hom teen die owerheid se inmenging in kerklike sake verset het en so aanleiding gegee het tot sy verbanning. Wanneer hy in 1541 na Genève terugkeer, gaan hy voort met sy pogings om die kerklike dissipline en opsig in die hande van die kerkraad te hou (Pont 1986:31; Buys 1980:100-105).

Calvyn het soos Zwingli die hele bevolking van Genève aanvaar as die gedoopte volk van God, maar hy aanvaar nie die totale identifikasie van kerk en volk nie. Die wending wat Calvyn meebring, is die resultaat van sy andersoortige kerkbegrip en beskouing van die verbond (Dreyer 1995:16). Die gedoopte kerkvolk is altyd corpus permixtum, waar ware en skyngelowiges vermeng tussen mekaar leef. Daarom moet onderskei word tussen die sigbare en die onsigbare kerk, waarvan God alleen kennis het. Die sigbare kerk is die uitwendige middel wat God daargestel het om deur die verkondiging en die bediening van die sakramente die mense tot verlossing te lei. Die kerk is dus nie insigself die heilsinstituut nie, maar verkondig slegs die heil wat in Jesus Christus gerealiseer het. Calvyn begrond dus die kerk Christosentries (Inst IV.1.1), maar ook verbondsmatig.

Waar Zwingli die verbond as 'n bilaterale verhouding tussen God en mens beskou het en sondermeer as die grond van 'n pneumatokratiese owerheid en 'n heilige Godstaat, het Calvyn die verbond meer as 'n testament beskou waar God sy genade aan die mens skenk deur die verdienste van Jesus Christus (Pont 1986:32). Dit lei daartoe dat 
Calvyn kon insien dat die wêreldse en kerkiike regering op verskillende vlakke staan en verskillend funksioneer en dat daar by hom gevolglik 'n groter skeiding tussen kerk en owerheid ontstaan as by Zwingli. Hierdie skeiding tussen die kerk en die owerheid was 'n voortgaande proses in die Calvinistiese politieke denke - ons vind byvoorbeeld by Beza, wat Calvyn in Genèye opgevolg het, 'n nog groter geskeidenheid tussen kerk en owerheid.

Dit is duidelik uit die politieke geskiedenis van Wes-Europa dat dir verbondsopvatting van Calvyn 'n groot invloed uitgeoefen het (Torrance 1990:1). Dit het die politieke vakuum ge wul wat ontstaan het met die beëindiging van die feodale stelsel. Dit het ook gedien as teenvoeter vir die opkoms van die oordrewe ius majestatis, of goddelike reg van die konings (Dreyer 1995:17). Die basiese probleem van die sestiende eeuse politiek was: hoe word die regte van die volk aan die een kant, en die regte van die owerheid aan die ander kant, omskryf? Die antwoord was: in terme van 'n verbond, waar die regte en pligte van die volk en die owerheid wedersyds omskryf is (Torrance 1990:9). Hierdie verbonde (waarvan daar talle voorbeelde bestaan), is met plegtige eedswering voor die aangesig van God gedoen. Hierdie tipe denke was moontlik omdat daar ' $n$ dualisme of pluralisme tussen owerheid en volk bestaan het. ' $n$ Vors het byvoorbeeld oor verskillende volke regeer, en die verhouding tussen die vors (owerheid) en ' $n$ bepaalde volk(e) en ook die verhouding tussen die volke onderling, is verbondsmatig/kontraktueel omskryf. Hiervar sê Torrance:

Here was a conceptual matrix (with its notious of natural law, contract, ius naturale, ius civile, ius gentium sovereignty etc. so familiar in Western Europe), within which Calvin's theology was readily reinterpreted as federal theology and went to the grassroots of nations and churches struggling for justice and liberty, seeking always biblical justification and precedent for their theology and practice ....

(Torrance 1990:11)

Calvyn se staatsbeskouing kan nie verstaan word as daar nie rekening gehou word met die feit dat hy ' $n$ bepaalde begrip van orde gehad het nie (vgl Milner 1970). Volgens Milner onderskei Calvyn drie sake waarin God orde geskep het, naamlik die kosmos, die mens en die samelewing. Met die sondeval verval die kosmos, mens en samelewing in wanorde. Om die orde te herstel skep God die owerheid en die kerk, om sodoende die sondige wanorde in die mens en samelewing deur die wêreldse en geestelike regeerwyses te beteuel. Beide die kerk en die owerheid het dus dieselfde doel in die 
$\infty$ g, naamlik om die mens ordelik, in liefde teenoor God en mens, te laat leef. Hiervoor gebruik die owerheid die swaardmag en die kerk die geestelike swaard, die Woord van God.

Hierdie beskouing van orde vorm ook die basis van Calvyn se teokratiese denke. Calvyn wys daarop dat ' $n$ goeie owerheid toesien dat die Tien Gebooie in die samelewing eerbiedig word. Die owerheid hoef dus nie nuwe wette te maak nie, maar moet net die Wet van God toepas. Die owerheid is dus aan die wet onderworpe. Dit staan in skrille kontras met die opkomende politieke filosofie van die tyd, waar die owerheid bo die wet verhef is (veral in Frankryk en Italiê), en die vors/owerheid as die bron van die wet beskou is en so ' $n$ godelike mag verkry het. Die teokratiese denke van Calvyn het die grondslag gelê vir wat ons vandag as die regstaat ken - met ander woorde 'n owerheid wat aan die wet onderworpe is. Dit is veral só omdat Calvyn se denke in Nederland gelei tot die Rechtstaat, en vandaar is die denke verder gedra (Dreyer 1995:230). Calvyn lê besondere klem daarop dat die regering met menslikheid (humanitas) en regverdigheid (iustitia) moet regeer (Inst IV.20.3/4/6/20/29/30/31). Dit het veral op die regspraak betrekking. Calvyn se uitspraak dat die regters in die samelewing die hoogste posisie beklee, is bekend. Hierdie denke het uiteraard bygedra tot die hoë waardering van die reg en die regstaat.

Ook in Calvyn se geval het sy spesifieke omstandighede bygedra tot sy beskouing van die verhouding tussen kerk en owerheid. Hy het in 'n situasie in Genève geleef waar daar een kerk, een volk en een owerheid was en waar die owerheid die Hervormde kerk goedgesind was. Dit het daartoe gelei dat hy die verhouding tussen kerk, volk en owerheid as een van organiese verbondenheid seskou het (Dreyer 1995:13). Die beeld wat hier na vore kom, is dié van 'n liggaam waarvan die owerheid die verstand, die volk die liggaam en die kerk die hart en siel is (Haitjema 1957:1138). Ander voorbeelde van ' $n$ organiese eenheid tussen kerk, volk en owerheid is: Nederland tydens die Goue Eeu, die Voortrekkers en ook die Transvaalse Republiek. In al hierdie gevalle was dit só, omdat hulle besonder sterk deur die Calvinistiese denke beïnvloed is (Dreyer 1995:40-56, 100-115, 157-180, 200-211). Dit is myns insiens die rede waarom daar vir baie jare 'n noue verbondenheid tussen kerk, volk en owerheid in die denke van die NHKA bestaan het.

Die organiese eenheid tussen kerk, volk en owerheid het nie vir Calvyn beteken dat die kerk in die volk opgeneem word nie, maar eerder dat die kerk met die kragtige Woord van God in die midde van die volk werk. Dit kom neer op 'n organiese askese, 'n dialektiese verhouding van in die volk werk, maar nie van die volk te wees nie. Die bepalende in hierdie verhouding is dus nie die volk of die owerheid nie, maar die kerk en die Woord van God. 


\subsection{Die Nederlandse Geloofsbelydenis}

'n Beiangrike dokument waarin die invloed van Calvyn sigbaar is, is die Nederlandse Geloofsbelydenis (NGB). Die opsteller van die NGB was Guido de Brês (1522-1567), 'n Calvinistiese predikant. Vanaf 1559 het hy te Doornik gewoon en daar die evangelie verkondig, hoewel hy as gevolg van die vervolgings van Filips II dikwels moes vlug. Ter wille van sy vervolgde geloofsgenote het hy in 1561 die NGB opgestel. Die NGB is waarskynlik al gedurende 1563 deur 'n geheime sinode van die Nederlandse Hervormde kerk as geloofsbelydenis aanvaar. Die Sinode van Antwerpen het dit in 1565 volledig hersien en as belydenis aanvaar. Die NGB is aan die hand van die Franse Geloofsbelydenis opgestel wat volledig deur die teologie en denke van Calvyn bepaal is (Bosman et al 1987:1-7).

As 'n mens na die teks van die NGB kyk, word dit duidelik dat dit onder andere as 'n apologetiese geskrif bedoel was. In die inleiding rig De Brês hom tot Filips II om te pleit om die koning se genade en om verder die hervormdgesindes se beskouinge uiteen te sit en te verdedig. Daarin kom iets van die verhouding tussen kerk, volk en owerheid na vore. In die verweerskrif word twee sake uiteengesit: allereers die verhouding van die Hervormde kerk teenoor Filips II en tweedens 'n uiteensetting van hulle geloof.

In sy uiteensetting van hulle verhouding met Filips II maak De Brês, soos Calvyn, van twee beginsels gebruik, naamlik natuurreg en die Woord van God. Daarom sê hy dat die verborge getuienis van hulle gewete en die Woord van God hulle leer dat rebellie en opstand teen die koning 'n gruweldaad is. De Brês sê in sy verweer dat die owerhede deur God ingestel is en dat dit deel van God se ordening van die wêreld is. Hierin sluit hy by Calvyn se opvatting van orde aan. Daarom is elkeen wat in opstand teen die owerheid is, in opstand teen die ordening van God. De Brês wou Filips II verseker dat die Hervormde kerk nie rewolusie of rebellie in die oog het nie, maar die ware geloof. Dit kan aanvaar word dat die hervormdgesindes bereid sou wees om onder Filips II se regering te staan, solank as wat die koning hulle die vryheid sou toelaat om die ware geloof te beoefen. Dit verklaar waarom Willem van Oranje aanvanklik nie teen Filips II in opstand wou kom nie. De Brês beroep hom verder op die humanitas van die koning, wat beteken dat hy in sagmoedigheid teenoor sy volk moet optree.

Die Calvinisties-teokratiese visie op die struktuur van die gemeenskap word duidelik in Artikel 36 van die NGB verwoord. Hierdie artikel het in die Nederlandse en Suid-Afrikaanse geskiedenis ' $n$ besondere groot invloed uitgeoefen, veral op die Afrikaner se denke oor die verhouding tussen kerk, volk en owerneid. Opsommenderwys kan 'n mens die hoofgedagtes soos volg groepeer: 
* Die sondeval het daartoe gelei dat God die owerhede daargestel het om orde te handhaaf.

* Die owerheid het die swaardmag om die wettelose mense te straf en die godvresendes te beskerm.

* Die owerheid moet nie net aan die staatsbestuur aandag gee nie, maar ook daarvoor sorg dat die ware geloof in Jesus Christus beskerm en bevorder word.

* Almal moet hulle aan die owerhede onderwerp.

* Die bedoeling van die ordelike regering is die rustige en stil lewe van die onderdane, sodat hulle in godsvrug kan volhard.

* Die wederdopers se verwerping van die gesag van die owerheid en kommunale besit word verwerp.

* Die owerhede moet gehoorsaam word in alles wat in ooreenstemming met God se Woord is.

* Daar moet vir die owerheid gebid word.

* Almal is belastingpligtig.

Wat belangrik is, is dat met Artikel 36 van die NGB 'n teokratiese verhouding tussen kerk, volk en owerheid bely word. Dit word dus as 'n Bybelse opdrag beskou dat die owerheid ook die evangelieverkondiging, en per implikasie die kerk van Christus, sal beskerm en bevorder. Binne hierdie gedagterigting is daar nie sprake daarvan dat alle godsdienste en selfs Christelike groepe, gelyke regte sou hê nie. Daar was net een waarheid. Dit is die taak van die owerheid om saam met die kerk te streef na die vasstelling van die waarheid en om dit dan te beskerm en te bevorder. Daarom dat die sinodes later deur die owerheid saamgeroep is om die ware leer vas te stel. Dit het die implikasie dat daar net een godsdiens onder ' $n$ volk behoort te bestaan. 'n Mens kan dit só formuleer: een volk, een owerheid, een geloof, een kerk. Die volk word regeer volgens die beginsels in God se Woord. So kom 'n teokrasie, dit wil sê 'n regering deur God ingestel, deur God bepaal en tot eer van God, tot stand (vgl Koopmans 1939: 244-279).

\subsection{Die Vindiciae contra tyrannos}

Die Vindiciae contra tyrannos [Brutus 1579] bly een van die heel belangrikste vir die verstaan van die Nederlandse politieke tradisie [De Visser 1926:89]. Dit het in 1579 in Edinburgh onder die skuilnaam Stephanus Junius Brutus verskyn. Dit word egter aanvaar dat die skrywer Languet of Du Plessis Mornay was. Die skrywer van die Vindiciae het sy geskrif gebou op Theodore Beza ([1574] 1956) se De iure magistratum. Deur Beza se gedagtes beter te verwoord en meer leesbaar te maak, het die Vindiciae 
baie groter impak gehad en is dit meer gelees. Die basiese gedagtegang is egter dié van Beza. Later sou min mense weet dat die Vindiciae nie volledig oorspronklik is nie (Van Schelven 1956:9-11). Beide Languet en Du Plessis Mornay was Franse wat die Bartlomeusnag beleef het, en geesgenote van Beza. Die Vindiciae argumenteer nie net teen die tirannieke optrede van die koning nie, maar ook teen die naturalistiese politieke filosofie wat aan die opkom was. Die volgende sake dien opgemerk te word: Die selfbeskikking van volke en groepe binne die gemenebes word gehandhaaf as 'n onvervreembare en Godgegewe reg, en die verhouding tussen die volke en die owerhede word kontraktueel bepaal. Regte en vryhede word in so 'n kontrak omskryf. So word die beginsel van politieke pluralisme in die Vindiciae gehandhaaf (Brutus 1972:90-93). Dit het die politieke beginsel gebly waarvolgens die Unie van Utrecht funksioneer het tot 1795 met die Bataafse rewolusie [Murray 1962:17]. Die situasie was só dat die Unie uit verskillende provinsies (volke) bestaan het, elk met sy eie laere vorste. Die koning het oor almal regeer, maar dit was nie 'n unitêre staat nie. Die verhouding tussen al hierdie partye, te wete die koning, die laere vorste en die volk word kontraktueel omskryf. Daarby word die verhouding wat bestaan tussen die owerheid/volk aan die een kant, en God/kerk aan die ander kant, in terme van die Ou-Testamentiese verbond verwoord. As voorbeeld word die verbondsluiting tussen Israel, Josua en God voorgehou. Die reg van opstand ontstaan eers wanneer hierdie verbondsverhouding deur die owerheid verbreek word, en slegs as die laere vorste die leiding neem in sodanige opstand.

Seker die belangrikste onderliggende probleem in die dokument is die handhatwing van 'n gesonde balans tussen die regte en vryhede van die volk teenoor die mag van die owerheid. Die Vindiciae se oplossing vir die probleem lê in die handhawing van die wet as hoogste gesag (Brutus 1972:73). Die magte van die owerheid word dus beperk deur die wet. Die wet, soos reeds angetoon, is die wet van God, en nie dit wat die owerheid na goeddunke uitvaardig nie. Daarmee saam word van die owerheid verwag om die wette van ' $n$ volk te eerbiedig.

Die kern van die Vindiciae se politieke denke is die volk (Brutus 1972:119-124). Die volk word beskou as ' $n$ Godgegewe ordening wat verder georden word in kleiner eenhede van families en gesinne. So word die gesin die boustene van die volk, maar ook van die kerk. Die kerk bestaan immers uit dieselfde gesinne wat verbondsmatig by die kinderdoop deel word van die kerk van Christus. Volgens die Vindiciae het elke volk sy eie identiteit, en bly die volk die subjek van die wet [Murray 1962:24]. Die regte van die volke bly deur al die eeue onveranderlik. Dit is nie die individu wat regte het wat beskerm moet word nie, maar wel die volk. Die individu se regte word beskerm in terme van die gemeenskaplike regte van die volksgenote. 'Die volk word dus eerstens as 'n juridiese en tweedens as 'n familiaal-kulturele entiteit beskou. 
Hier is geen sprake van ' $n$ individualisme nie. Toe die Unie van Utrecht in 1579 gesluit is, moes dit $r \epsilon=d s$ met ' $n$ nuwe politieke fenomeen rekening hou, naamlik die individu en sy regte. Net ' $n$ paar dekades later sou Hobbes sy politieke teorie oor die individu, met al sy natuurlike regte, formuleer. Die ironie van die saak is dat in die individualisme van Hobbes 'n staat nodig word wat die individu se regte en magte feitlik tot niet maak [Van Eikema Hommes 1979:102-103]. In die Vindiciae is daar nie sprake van die individu met regte nie.

Dit moet in gedagte gehou word dat die Vindiciae sy oorsprong het in die tyd van die godsdiensoorloë wat in Europa gewoed het, en daarom was die verhouding tussen die kerk en die owerheid ' $n$ besonder aktuele probleem. In die Vindiciae word die owerheid opgeroep om nie net tot beswil van die volk nie, maar ook tot voordeel van die kerk te regeer. Verder word gestel dat die owerheid, asook die volk, aan die wet van God onderworpe is. Die teokrasie word dus as vanselfsprekend aanvaar. Die gedagte van die NGB word weer herhaal, naamlik dat die owerheid nie net die kerk moet beskerm nie, maar ook aktief moet meewerk tot die groei en verbreiding van die kerk, en die handhawing van die ware leer. Murray som die verhoudit. owerheid soos uiteengesit in die Vindiciae soos volg op:

Its principles are clear. The magistrates must serve the church and must protect her. But more: their duty is actively to promote the spread of the interests and the teachings of the church. These points mark one of the main distinctions in the cleavage which occurs in subsequent political theories. Natural Law theories of the naturalist type assert the sovereignty of the state and so place the church under the state; or at best make one religious denomination a national church. The old tradition continues to maintain the principle that the secular institutions of the state have their duties to the church. Its principle of the spiritual universality of the church with its earthly pluriformity enables it to stand for the principle of religous rights, and not merely plead for toleration. To this extent it adapts itself to new conditions. It maintains the principle of corporative autonomy of the church, and of the duty of the secular authorities to maintain, defend and extend the Christian religion.

(Murray 1962:25)

\subsection{0 'n Suid-Afrikaanse voorbeeld}

Deur die hele geskiedenis van die Afrikanervolk en die Kerk in Suid-Afrika, was daar 'n noue verbintenis tussen kerk, volk en owerheid (vgl Dreyer 1995). Twee doku- 
mente waarin dit baie duidelik word, en wat hier eksemplaries aan die orde gestel word, is die Grondwet van die Zuid-Afrikaansche Republiek van 1858, en die voorlopige Kerkwet van die Nederduitsch Hervormde Kerk van 1858.

Eerstens die Grondwet: Die Nieuwe Wetten van 1855 (wat die basis vorm van die 1858 Grondwet) omskryf die Hervormde Kerk se voorregte en posisie in die ZAR breedvoerig. Die volgende artikels raak die kerk direk:

Artikel 10: Het (volk) verlangt de uitbreiding van het Christendom onder de heidenen, doch onder bepaald voorzorgen tegen misleiding en bedrog. Artikel 12: Het (volk) behoudt uitsluitend aan zich de bescherming en verdediging van Kerk en staat.

Artikel 17: Het (volk) zal jaarlyks, van den volksraad, eene begrootingswet van algemeene uitgaven voor Kerk en staat inwachten.

Artikel 23: Het volk wil zyne Nederduitsch Hervormde godsdienst, zoo als die in de jaren 1618 en 1619 door de synode te Dordrecht is vasgesteld, behouden.

Artikel 24: Het (volk) verkiest in zyn midden geene Roomsche Kerken toe te laten en ook geene ander Protestantsche dan de zoodanige, waarin dezelfde hoofdzom van Christelyk geloof geleerd wordt, als is opgegeven in de Heidelbergsche Catechismus.

Artikel 25: Het (volk) zal geene andere vertegenwoordigers in den volksraad aanstellen, dan degenen die lidmaten der Nederduitsch Hervormde gemeente zyn.

Artikel 26: Het (volk) erkent geen ander Kerkelyk gezag dan dat, wat door Kerkeraden zyner Ned. Hervormde gemeenten is of wordt goedgekeurd, aangenomen en vasgesteld.

Artikel 27: Het (volk) wil zyne Kerk niet minder ongeschonden bewaren, dan de onafhankelykheid van zynen staat.

Artikel 29: Het volk verlangt de opbouw, bloei en welvaart van Kerk en staat en uit dien hoofde, voorziening in de behoeftc aan Ned. Hervormde predikanten en schoolonderwyzers.

(SA Argiefstukke Tvl.no.3:382)

In hierdie aanhaling is volk by sommige artikels in hakies geplaas, omdat dit nie so in die oorspronklike teks voorkom nie. Tog is dit baie duidelik uit die konteks van die hele dokument, asook die gebruik van volk by ander artikels, dat die veronderstelling is 
dat die volk bepaalde dinge vereis of verlang. Dit is die volk wat die Nederduitsch Hervormde Kerk (NHK) as die bevoorregte, staatskerk (en dus volkskerk) erken. Ook ander bepalings raak die verhouding tussen die kerk en die owerheid, onder andere dat die staatspresident ' $n$ lidmaat van die Hervormde Kerk moet wees (Artikel 34), en dat die onderwysers direk onder toesig van die predikante staan (Artikel 236).

Die finale Grondwet is op 5 Maart 1858 in die staatskoerant gepubliseer onder die titel Grondwet van de Zuid-Afrikaansche Republiek (SA Argiefstukke Tvl. no.3:496). Dit is duidelik dat die Transvaalse Afrikaners oortuigde republikeine was. Die heel eerste artikel van die Grondwet stel dit duidelik dat die regeringsvorm van deze maatschappij zal zyn Republikeinsch. Hand aan hand met die republikeinse ideaal loop die strewe na staatkundige vryheid wat in verskillende artikels aan die orde kom. Vir die Afrikaner in die Transvaal was selfbeskikking en politieke vryheid die hoogste ideaal. Verskeie artikels begin met die woorde het volk wil. Die volk, en nie die individu nie, was die kern van die Transvaalse Afrikaners se politieke denke, want die volk is soewerein en die hoogste gesag.

Pont wys daarop dat in die Transvaalse volkswil die individu byna geen rol speel nie. Die Transvaalse opvatting van die volk is meer Calvinisties bepaald, naamlik as 'n verbondsvolk van gedooptes. Hierdie verbondsvolk word saamgestel deur families, eerder as individue [Pont 1986:62]. D W Krüger het daarop gewys dat president S J P Kruger die volk as sy eie mense (die Afrikaners in Transvaal) beskou het, mense wat God se volk is omdat hulle nie net Afrikaners was nie, maar ook lidmate van die kerk. Dit was verbondskinders oor wie hy soos ' $n$ Moses moes regeer en moes waak. Die vryheid en onafhanklikheid van hierdie volk moes soos 'n kleinnood bewaar word, want dit is uit die hand van God ontvang (Krüger 1963, II:86).

Die Redelyke Godtsdienst van W à Brakel (á Brakel 1736) het groot invloed uitgeoefen op die denke van die ou Transvaaise Afrikaners. Dit blyk onder andere uit 'n opmerking in die notule van die sewende Algemene Kerkvergadering, naamlik dat die Kerkwet voorlopig in werking gestel moet word, en dat daar 'n byvoegsel moet kom wat die verhouding tussen kerk en owerheid sou omskryf 'en wel volgens't geen men daarvan vind in W à Brakel' (Notule AKV 1857:26]. à Brakel se denke oor die verhouding tussen kerk en owerheid, die rol van die kerk in die politiek en die aflê van geloftes het waarskynlik die 1858 Grondwet beïnvloed. Deur middel van à Brakel het die beginsel van ' $n$ teokratiese gemenebes in die ZAR aanvaarding gevind. Daarom wou die Transvalers ' $n$ teokraties-Christelike gemenebes oprig, maar wel as 'n republiek. So vind in die Grondwet van die ZAR ' $n$ unieke vermenging van Calvinistiesteokratiese en Patriot-republikeinse denke plaas, met eersgenoemde waarskynlik die dominante. 
As gekyk word na die uitleg van die Grondwet wat in die notule van die Kommissie van die Algemene Kerkvergadering te vinde is (Notule Kommissie AKV Augustus 1862:97), word die Calvinisties-teokratiese denke nog meer sigbaar. Die Algemene Kerkvergadering het in September 1861 van die owerheid 'n uitleg van Artikels 8, 9, $11,20,21,22$ en 23 van die Grondwet gevra. Op 2 Augustus 1862 het die fungerende staatspresident en 'n afvaardiging van die Volksraad, die Kommissie van die AKV ontmoet en die artikeis uitgelê.

Allereers wou die AKV weet wat bedoel word as in Artikel 8 gesê word dat 'Het volk eischt ... het behoud van zyn Godsdienstig Geloof'. Die antwoord was dat Godsdienstig Geloof beteken 'Ned. Herv. Kerk'. Die owerheid bevestig hiermee dat die Hervormde Kerk nie net staatskerk van die ZAR sol wees nie, maar ook die bevoorregte kerk wat beskerm moes word, soos wat Artikel 36 van die NGB van 'n owerheid vra. Hier is geen sprake van skeiding tussen kerk en staat nie, slegs ' $n$ onderskeid (Engelbrecht 1953:135). Die bevoorregting van die Hervormde Kerk het onder andere beteken dat die predikante se traktement uit die staatskas betaal sou word, dat die owerheid sou help met die oprigting van kerkgeboue, dat die owerheid die predikante se pensioen sou waarborg en dat alleen lidmate van die Hervormde Kerk in die Volksraad en in die staatsdiens toegelaat sou word. Hieroor sê Pont (1991:792):

So is die Kerk, hoewel staatskerk, nié 'n Kerk-van-die-staat nie, maar Kerk-in-die-gemeenskap ten behoewe van die volk wat die staatsgesag in sy hande hou. In die teokratiese Christelike gemenebes word die Kerk omskryf as 'n eiesoortige grootheid wat, omdat dit dan nog die hele burgery omvat, ook deur die burgery ondersteun en in stand gehou sal word.

In die ZAR het die Hervormde Kerk nie tot 'n staatsdepartement verword soos dit in Nederland en ook in die Kaap die situasie was nie. Die Calvinistiese gedagte dat daar 'n onderskeid tussen die kerk en die owerheid moet bly bestaan en dat elkeen eie bevoegdhede het, word hier gehandhaaf. As van die Hervormde Kerk as staatskerk gepraat word, is dit nie in sy verworde vorm nie, maar is dit waar die owerheid die kerk in die lig van Artikel 36 van die Nederlandse Geloofsbelydenis bevorder en beskerm. Daarom laat die Grondwet ook nie die Rooms-Katolieke Kerk in die ZAR toe nie - dit sou strydig wees met bogenoemde. Veeleerder moet aan die Hervormde Kerk as staatskerk gedink word as volkskerk, gesien in die lig daarvan hoe sterk die volkssoewereiniteit in die ZAR gefunksioneer het. Hier is geen skeiding tussen volk en staat (owerheid) nie. Die volk is die staat - daarom is staatskerk of volkskerk, in die ZAR se geval, sinonieme. 
Die Grondwet v 1858 handhaaf die organiese eenheid van kerk, volk en owerheid (Pont 1986:63). Artikel 20 van die Grondwet bepaal nie net dat die Hervormde Kerk staatskerk is nie, maar dit bepaái ook die aard van die volk en die owerheid wesenlik. Die situasie wat die Grondwet van 1858 in die ZAR geskep het, was dat die owerheid net een kerk (dir Nederduitsch Hervormde Kerk) erken het; dat daar net een volk was wat sy volkslewe volgens christelike beginsels wou inrig; en een owerheid wat bereid en begerig was om hierdie kerk en volk ten alle koste te beskerm.

Tweedens die Kerkwet: Op die sewende Algemene Kerkvergadering, gehou vanaf 22 Desember 1857 te Potchefstroom, word die Kerkwet wat ds Dirk van der Hoff opgestel het, in behandeling geneem; en word daar drie belangrike besluite geneem: Eerstens dat die Kerkwet voorlopig in werking gestel word, en dat vanaf die datum lidmate ' $n$ jaar het om veranderinge aan die wet voor te stel. Die wet was dus nog nie amptelik nie vanweë hierdie besluit van die Algemene Kerkvergadering en vanweë die feit dat dit nie deur die Volksraad goedgekeur is nie. Tweedens word daar besluit om in 'n byvoegsel, die verhouding met die ander gereformeerde kerke in Suid-Afrika uiteen te sit, naamlik dat die kerk in die ZAR selfstandig is, maar tog een met alle ander gereformeerde kerke in die wêreld. Derdens word daar besluit om in nog 'n aanhangsel die verhouding tussen die kerk en die owerheid duidelik uiteen te sit '... en wel volgens't geen men daarvan vind in W. à Brakel' (Notule AKV 1857:26). Dit is die eerste maal dat daar na 'n spesifieke teoloog verwys word om hierdie verhouding tussen kerk, volk en owerheid te omskryf.

Wat in die voorlopige Kerkwet van 1858 van belang is, is hierdie byvoegsel aan die einde wat in opdrag van die AKV bygevoeg is en wat die verhouding tussen die kerk en die owerheid uitspel (SA Argiefstukke Tvl.no.3 1858:575). In die formulering van hierdie saak kan 'n mens redelikerwys aanvaar dat Van der Hoff, wat die Kerkwet moes optel en die enigste opgeleide teoloog was, die leiding geneem het. In 'n sekere sin sal dit dus nie net á Brakel se denke weerspieël nie, maar ook dié van Van der Hoff. Die formulering lui soos volg:

Geen Gouvernement of wereldlyk bestuur heeft eenige magt in de Kerk, maar wel om de Kerk; dat is, het gouvernement beschermt de Kerk en bezoldigt hare leeraren, wordende het geheel en al aan de opzieners der Kerk overgelaten de inwendige zaken der Kerk te besturen en al dat gene te doen, wat duidelyk vervat is in de formulieren onzer Kerk over de bevestiging van ouderlingen diakenen en Predikanten. Geen Gouvernement of gouvernements-ambtenaar heeft als zoodanig regt, inzage te vor- 
deren of te eischen van de inwendige Kerkeliyke zaken; alleenlyk als ledematen der Kerk kunnen zy op den daartoe vasgestelde tyd en plaats daarvan inzage neem.

(SA Argiefstukke Tvl.no.3 1858:575)

Met hierdie besluit loop die Algemene Kerkvergadering dan inderdaad op die spoor van á Brakel wanneer daar beklemtoon word dat die owerheid geen mag 'in' die Kerk het nie, maar alleen 'om' die kerk (Pont 1986:65). Die woordjie 'om' kan ook vertaal word met ter wille van. Die owerheid het dus mag ter wille van die kerk, dit wil sê,, die mag om die kerk te beskerm en te bevorder. Dit is ook in lyn met wat die Nederlandse Geloofsbelydenis sê van die magte van die owerheid: '.. om te weren en uit te roeien alle afgoderij en valschén godsdienst, om het rijk der antichrist te gronde te werpen en het Koninkrijk van Jezus Christus te doen vorderen ....' (teks in Bakhuizen van den Brink 1940:137). Die Calvinistiese beginsel dat die owerheid 'n ius circa sacra het, maar nie ' $n$ ius in sacra nie, word hier toegepas.

Pont wys daarop dat die artikel nie á Brakel in alle opsigte navolg nie (Pont 1986: 65]. á Brakel sê óók dat die owerheid 'een bedwingende macht omtrent de Kerkelyke saken het' (á Brakel 1736:693). Dit sou die ideale begronding gebied het vir die owerheid om met mag teen die skeurmakers in die Transvaalse Kerk op te tree. Die feit dat dit juis nie hier vermeld word nie, dui dalk op Van der Hoff se beskouing dat in 'n republiek godsdiensvryheid moet geld, soos hy ook in die Algemene Kerkvergadering bepleit het (Notule AKV 1853:3).

Die gevolgtrekking is dat hoewel die Nederduitsch Hervormde Kerk staatskerk van die Zuid-Afrikaansche Republiek was, dit nie beteken het dat die staat ingemeng het in kerklike sake, of voorgeskryf het of dwingend opgetree het nie. Aan die ander kant wou die Hervormde Kerk nie op die terrein van die owerheid oortree nie. Die Hervormde Kerk as staatskerk, was tegelykertyd volkskerk. Kerk, volk en owerheid het in voortdurende wisselwerking en interaksie geleef, mekaar wedersyds beïnvloed (ten goede of kwade), binne die interessante en unieke vermenging van republikeinse en Calvinistiese waardes.

\subsection{Karl Barth}

Barth het in sy lesings oor die Apostolicum onder andere oor die verhouding tussen kerk, volk en owerheid gehandel (Barth 1935:164-178). Daar word slegs by hierdie paar gedagtes stilgestaan, hoewel hy (en ander teoloë van die twintigste eeu) heelwat meer oor die owerheid geskryf het. Barth se nadenke hieroor moet 'n mens lees teen die agtergrond van sy kritiek teen Hitler en die Nasionaal-Sosialisme in Duitsland. 
In sy behandeling van die belydenis oor die een heilige algemene kerk en die gemeenskap van die heiliges, wys Barth daarop dat die kerk teenoor alle ander vorme van groepe staan. Die kerk is iets anders as byvoorbeeld 'n gesin, ' $n$ volk, 'n staat of rasse-, kulturele- of taalgemeenskappe (Barth 1935:165). Hierdie groepe en gemeenskappe bestaan op ' $n$ natuurlike wyse, en kan deur middel van verdrae hulle onderlinge verhoudings reël. Die kerk bestry ook nooit hulle reg om te bestaan nie, maar erken dit ten volle. Aan die lidmate van die kerk is van die vroegste tyd gesê (verwysend na Rom 13) dat dit op 'n Goddelike verordening berus dat daar owerhede en gesagsdraers bestaan. Die owerheid moet ook gehoorsaam word. Teenoor die owerheid moet eer bewys word, voorbidding gedoen word en belasting betaal word.

Die kerk is onderskeibaar van al hierdie groepe, omdat die kerk die gemeenskap van die heiliges is. Daarom staan en val die kerk nie by een van die ander gemeenskappe nie. Die kerk is nie gebonde aan hulle onderlinge geskille of aan hulle grense nie. Die kerk se grense loop dwars oor alle ander grense. Die kerk het, te midde van hierdie ander groepe en gemeenskappe, sy eie belange, doel en arbeid om te verrig. Dit impliseer ook dat geen binding aan ' $\mathrm{n}$ volk, staat of kultuur ooit die katolieke aard van die kerk mag negeer nie. Die kerk is alleen kerk, die kerk is alleen heilig as die kerk ook katoliek is. Dit is die primêre van kerkwees. Die kerk moet dus allereers vraag vra hoe dit een, heilige en algemene kerk is, voordat die vraag na die binding aan ander groepe soos volk en staat gevra word. Dogmaties gesproke is die vraag na die verhouding tussen kerk, volk en owerheid 'n sekondêre vraag, omdat dit nie met die wese van die kerk te doen het nie, maar met die kerk se organisasie. Die kerk kan organisatories volkskerk, landskerk, staatskerk of vrye kerk wees, en steeds katoliek en heilig wees (Barth 1935:166). Dit verteenwoordig in 'n groot mate Barth se antwoord op Gogarten se vraag of die kerk volkskerk of belydende kerk moet wees (Miskotte 1935:331).

Die kerk is in sy regering nie gebind aan enige mag nie. Die kerk se enigste Hoof en Heer is Jesus Christus. Die kerk leef in gehoorsaamheid aan Hom, en dit impliseer 'n apostolêre gerigtheid op die wêreld (Matt 28). Die kerk werk binne die menselike geskiedenis op 'n bepaalde plek. So word die kerk sigbaar. Die kerk word egter nooit die domein van die mens nie, maar staan onder die volstrekte alleenheerskappy van Christus. Slegs wanneer die kerk se apostolêre taak in gehoorsaamheid aan Christus alleen aanvaar word, is dit werklik gemeenskap van die heiliges (Barth 1935:172).

Barth vra die kritiese vraag of daar enigsins Christelike wetenskap, Christelike politieke partye, Christelike koerante en dies meer moet wees of kan wees (Barth 1935: 172). Dit hang saam met Barth se beskouing dat die kerk net een roeping en taak het, en dit is die verkondiging van die Woord en die evangelie. Barth het verskillende male 
kritiek uitgespreek teen predikante wat preekmoeg is, nie tyd het om preke voor te berei nie maar in allerlei sosiale aksies betrokke raak, onder die voorwendsel dat hulle dit ter wille van die kerk doen (Miskotte 1935:339).

\section{PROBLEEMSTELLING}

Bogenoemde is enkele kerngedagtes oor die verhouding kerk - kultuur - volk owerheid. Daar bestaan nog talle filosofiese, staatsregtelike en ander teologiese beskouings hieroor. Ter wille van bondigheid word met bogenoemde volstaan as 'n seleksie van denke uit die Bybels-reformatoriese tradisie. Die magdom ander politieke teorieë wat deur die eeue ontwikkel het, kan uiteraard nie behandel word nie. Dit is deur die hele geskiedenis opmerklik dat mense uit 'n Calvinistiese agtergrond 'n lewendige belangstelling in die politiek het (McNeill 1967:411). Dit was ook in die Afrikanervolk en kerk se geskiedenis só. Dit is deel van die Calvinistiese erfenis, om teenoor die owerheid en volk te getuig. 'n Groot deel van die politieke teorie en beginsels wat in die Suid-Afrikaanse opset gebruik word, het hulle oorsprong by die Calvinistiese politieke teorie. Die ironie is dat die Calvinistiese kerke dikwels swyg oor sake wat uit hulle eie teologiese tradisie na vore gekom het.

Daar is talle vrae oor die verhouding kerk, kultuur, volk en owerheid. Die saak was altyd baie kompleks, maar is verder gekompliseer deur die politieke veranderinge in Suid-Afrika na 1994. Die problematiek moet (wat die kerk betref) teologies-krities ondersoek en beantwoord word. Sommige van die probleme kan soos volg geformuleer word:

* Is 'n volkskerk nog ho'ıdbaar?

* Wat is die verhouding tussen die NHKA en die ANC-regering?

* Kan daar nog van volke gepraat word in die nuwe situasie?

* Is uitsprake van die verlede deur die NHKA oor volkereverhoudings en die owerheid, nog relevant en houdbaar?

* Wat is die NHKA se standpunt teenoor regeringsbeleid, en hoe word teenoor die owerheid van die evangelie getuig?

* Het die NHKA 'n kultuurtaak?

* Hoe begelei die NHKA die Afrikaners in 'n situasie waar hulle vir alle praktiese doeleindes alle politieke mag verloor het, en op die punt staan om ook kultuurvoorregte (skole/Afrikaans op televisie ensovoorts) te verloor?

* Moet die NHKA ten opsigte van politieke beleid uitsprake maak?

* Wat is die NHKA se standpunt ten opsigte van 'n staat waar godsdiensgelykheid op alle vlakke bevorder word, en die uniekheid van die Christelike geloof misken word? 


\section{GEVOLGTREKKINGS}

Daar kan nog talle vrae en probleme by die lys gevoeg word. Sonder om te probeer om alle hierdie vrae te antwoord, kan daar tog, in geen spesifieke volgorde nie, enkele opmerkings en gevolgtrekkings gemaak word:

\subsection{Kerk en kultuur}

Die kerk in Suid-Afrika beleef in die afgelope tyd kulturele grondverskuiwings. Afgesien van die politieke oorsake wat hierin 'n rol speel, kan verskillende ander oorsake aangetoon word:

* Internasionaal het die postmoderne denke groot veranderings in lewens- en wêreldbeskouing tot gevolg gehad;

* deur die massamedia het die wêreld 'n sogenaamde global village geword;

* talle gemeenskappe is bekommerd oor die veramerikaansing van hulle kultuur en die ontstaan van 'n sogenaamde wêreldkultuur;

* wetenskap, industrie en teghologie het die mens se kultuur en wêreld radikaal verander.

* onderwys in Suid-Afrika is besig om ingrypend te verander;

* wat die Afrikanervolk betref, beleef die volk veranderings wat sy taal, kultuur, politiek, onderwys en sosiale opvattings ingrypend beïnvloed;

* dit moet voorsien word dat Afrikanerkinders binne 'n relatief kort tydsverloop 'n radikaal ander lewens- en wêreldbeskouing gaan hê as hulle ouers, veral as gevolg van nuwe leerplanne wat in die skole ingevoer word en die invloed van die media.

Wat is kultuur? Om 'n omskrywing van iets soos kultuur te gee, is nie so maklik nie. Kultuur manifesteer nie net uiterlik in byvoorbeeld die beeldende kunste, argitektuur, taal, letterkunde, musiek, spcl, staatsvorming, landbou, industrie en in die wetenskap nie - dit is ten diepste ' $n$ wesenskenmerk van die mens. Die mens bedryf nie kultuur nie, hy/sy is kultuur. Selfs iemand wat sogenaamd ongekultiveerd is, is juis só besig om ' $n$ bepaalde kultuur daar te stel. Kultuur is spesifiek menslik (De Vos 1975:158). Diere ken nie kultuur nie.

Kultuur is ook 'n bepaalde omgaan met die natuur. Tradisioneel word daarop gewys dat Genesis 2:15 die kultuuropdrag aan die mens is, waar God die mens beveel om die tuin te bewoon en te bewerk. Die bewerking van die natuur word kultuur. Die mens omskep die natuur tot lewensruimte, en in die proses kom kultuur tot stand. Daarom dat ons woord kultuur afgelei word van die Latynse woord colere, wat beteken 
om te bou of om te bewerk. Sonder die natuur is daar geen kultuur nie, want die natuur verskaf die materiaal waarmee skeppend omgegaan word. Wat maak Afrikaners anders as Nederlanders? Die antwoord: vir negentig persent hulle andersoortige omgaan met die natuur. Die bodem van Afrika is anders as dié van Europa. Pioniersomstandighede in Afrika het van Afrikaners gemaak wat hulle is.

Kultuur het te doen met die denke, ingesteldheid, emosie, waardes en geloof van mense wat uitmond in menslike interaksie binne die kollektiewe strukture van die ekonomie, politiek, families en godsdiens (Van Aarde 1996:6). Kultuur is gevolglik die produk van 'n bepaalde gemeenskap (De Vos 1975:162). Kultuur word nie net deur enkelinge beoefen nie, dit geskied in gemeenskap met ander mense. As mense binne 'n bepaalde tyd en ruimte op 'n soortgelyke wyse met die natuur omgaan, kom daar nie net ' $n$ bepaalde kultuur of subkulture tot stand nie, maar ook 'n groep, samelewing of volk. Groepe of volke word van mekaar onderskei op grond daarvan dat hulle verskillende kulture het.

Dit is nie sonder rede dat die mens kultureel besig is nie. Daar sit ' $n$ bepaalde doel daaragter. Allereers het kultuur die vorming van die mens as mens, die ontplooiing van sy/haar menswees in die oog (Waterink 1957:xxvi]. Mense se kultuuraktiwiteit is ook gerig op hulle oorlewing. As mense alle kultuuraktiwiteit staak (byvoorbeeld voedselproduksie), sal hulle uitsterf. Dan oorwin die natuur en word die mens (wat oorbly) verdierlik.

Met hierdie enkele oorsigtelike opmerkings word dit duidelik dat as die kerk se evangelieverkondiging op die mens gerig word, dit gerig is op die mens wat kultuur is. Daarom is dit noodwendig dat die kerk met kultuur erns sal maak - nie soseer omdat die kerk die kultuur wil vorm nie, maar omdat 'n deeglike kennis van die mens 'n deeglike kennis van die nens se kultuur impliseer. As die evangelie werklik tot die hart van mense wil spreek, moet dit inheems word aan 'n bepaalde kultuur. Maar tegelykertyd is dit vanselfsprekend dat wanneer mense die evangelie ter harte neem, dit indirek vormend sal inwerk op hulle kultuur. So het duisende jare se verkondiging van die evangelie ons persepsie en optrede in die huwelik, kinderopvoeding, arbeid, moraliteit en vele meer wesenlik bepaal. Sonder twyfel het die evangelie 'n geweldige invloed op die Afrikanerkultuur uitgeoefen. Nog duideliker is die invloed wat die verkondiging van die evangelie op die Swart kulture in Suid-Afrika uitgeoefen het. Die kerk se primêre taak is nie om kultuur te vorm nie, maar dit het deur die verkondiging ' $n$ indirekte invloed daarop. 


\subsection{Die verhouding tussen die NHKA en die Afrikanervolk}

Deur die hele bestaan van die NHKA was hy 'n volkskerk. Die organiese verbintenis (Calvyn) tussen die Nederduitsch Hervormde kerk en die Afrikanervolk is 'n historiese gegewene. Hierdie verbintenis, veral met die nawerking van Apartheid, is besonder negatief deur kerke wêreldwyd beoordeel. Die saak is vererger deur die handhawing van Artikel III van die Kerkwet van die NHKA wat lidmaatskap tot Blankes beperk het. Tog is dit vreemd, aangesien talle Europese teoloë nie wesenlik beswaar het teen iets soos 'n volkskerk nie (met sekere kwalifikasies, soos aangetoon by Barth). Talle kerke in Europa en in die VSA funksioneer ook de facto as volkskerke. In talle kerkgeboue in die VSA wapper byvoorbeeld Amerikaanse vlae. In Suid-Afrika bestaan die Lutherse Kerk steeds as 'n eiesoortige, Duitssprekende kerk. Daar kan geen twyfel wees oor die noue verbintenis tussen die Nederlandse Hervormde Kerk en die Nederlandse volk, geskiedenis en owerheid nie. Daarom het Haitjema, in sy 'perspektiefbeskrywing' van die Nederlandse kerkgeskiedenis daartoe gekom om die Nederlandse Hervormde Kerk 'n Christusbelydende volkskerk te noem (Haitjema 1964:10). Die enigste gevolgtrekking wat 'n mens kan maak, is dat in die Suid-Afrikaanse situasie, iets soos 'n volkskerk as rassisme beskou is.

Amptelik het die NHKA deurlopend uitsprake gemaak teen die volkskerklike opvattings van Kuyper (massakerk) en dié van die Duitse sendingwetenskaplikes waarvolgens 'bloed en bodem'-sake die kerkbegrip wesenlik beïnvloed het. Invloedryke voorstanders van die volkskerkidee in die NHKA het hulle eerder geskaar by die denke van Hoedemaker, Haitjema en Van Ruler oor die volkskerk (Van der Wethuyzen 1981:2123). Hulle sluit by die organiese kerkbegrip van Calvyn aan. Volgens hierdie beskouing is die kerk die hart en siel en die owerheid die organe (hart en verstand) van die liggaam.

Dit is my mening dat die volkskerkdenke gehandhaaf kan word. Maar dan moet dit, soos Barth dit gestel het, 'n sekondêre saak bly en dit moet nie die algemeenheid en heiligheid van die kerk in die gedrang bring nie. Solank as wat dit 'n organisatoriese saak bly, kan die beskouing gehandhaaf word dat die NHKA apostoler op die Afrikanervolk gerig is. Miskien het die tyd aangebreek dat die NHKA besef dat die 'vanselfsprekende' sendingterrein nie die Swart volke in Suid-Afrika is nie, maar die Afrikanervolk. Juis nou, met die ontkerstening van die Afrikaner wat al vinniger toeneem, moet die NHKA hierdie apostolêre roeping al meer uitleef. Dit is die plek waar die kerk sigbaar word. Die NHKA kan in 'n egte ekumeniese verhouding en in ware geloofseenheid met 'swart' kerke leef. Kortliks opgesom kan die NHKA se verhouding met die Afrikanervolk op 'n dialektiese wyse beskryf word as: 
* Profeties-apostolêr; en

* krities-solidêr.

Dit impliseer dat die NHKA nooit die spanning tussen kerk en volk kan ophef nie. Die kerk behoort nie aan die volk nie, maar aan Christus. Die kerk leef altyd krities teenoor die volk, maar tog in verbondenheid met die volk onder wie die kerk die evangelie verkondig. So word die kerk ook inheems. Die kerk bly altyd 'n eskatalogiese gemeenskap, wat vreemd is aan die wêreld en totaal verskil van die volk. Ten spyte daarvan leef die kerk nie bowetydelik, onhistories en bowêrelds nie, maar in die tyd en ruimte. Die kerk moet ook konkreet word, en die evangelie a Daardie adres - wat die NHKA betref - is in die eerste plek die Afrikanervolk. Die NHKA bid, preek en sing in Afrikaans. Daar is dus baie duidelik 'n dialektiese verhouding tussen die Nederduitsch Hervormde Kerk en die Afrikanervolk.

\subsection{Die verhouding van die NHKA met die owerheid}

Die verhouding tussen kerk en owerheid kan op verskillende vlakke funksioneer. Hierdie veelkantigheid van die verhouding kerk/owerheid moet altyd in die oog gehou word.

Eerstens bestaan daar 'n juridiese verhouding tussen die kerk en owerheid. Die huidige owerheid is ' $n$ wettige owerheid wat deur die totale internasionale gemeenskap as wettig aanvaar word. Die uwerheid het deur middel van 'n demokratiese verkiesing aan bewind gekom. Die kerk sou dus op geen wyse verset teen die owerheid, op grond van die wettigheid van die regering, kon steu. nie. Tegelykertyd beteken dit dat die kerk aan die wette wat die owerheid maak, onderworpe is vir sovêr hierdie wette nie strydig is met die Woord van God nie. Die aanvaarding van die owerheid se gesag bly 'n Bybelse opdrag (Rom 13), 'n saak wat in die Belydenisskrifte bely word (Artikel 36 van die NGB) en ook 'n gewetensaak is (Rom 13:5). Die juridiese verhouding impliseer nie dat die owerheid die kerk dwing om gehoorsaam te wees aan die wette van die land nie, maar vir 'n Christen is dit 'n gewetenssaak. Daarom betaal Christene belasting, beywer hulle hulle vir wet en orde en so meer. Die grens van hierdie gehoorsaamheid bly ook staan, naamlik dat die kerk die owerheid in alles gehoorsaam moet wees wat nie strydig is met die Woord van God nie. Die kerk moet immers God meer gehoorsaam as die owerhede van hierdie wêreld (vgl Hand 5 asook Calvyn se interpretasie daarvan).

Hierdie juridiese verhouding tussen kerk en owerheid het velerlei praktiese implikasies, onder andere dat die owerheid subsidies aan die kerk uitbetaal ten opsigte van barmhartigheidsdiens. Dit raak dan uiteraard die toelatingsbeleid by ouetehuise en 
kiderhuise van die kerk. As die kerk nie kan aantoon dat daar artikels in die Handves van Menseregte is wat strydig met die Skrif is nie, sal die kerk juridies en as gewetensaak verplig wees om volgens die Handves die kerk se eie sake te reël - wat ook weer implikasies het vir lidmaatskap van die kerk.

Die verho:s ding tussen kerk en owerheid kan ook organies van aard wees. 'n Organiese verhouding was die vanselfsprekende verhouding in Genève gewees tussen kerk en owerheid tydens Calvyn se verblyf daar, in cie Necierlande tydens die Goue Eeu, onder die Voortrekkers en in die Zuid-Afrikaansche Republiek gedurende die negentiende eeu. Die politieke werklikhede van die twintigste eeu het Suid-Afrika ook ingehaal, naamlik dat die organiese eenheid tussen kerk, volk en owerheid 'n vergete ideaal is. Die veelheid van kerke en volke in Suid-Afrika maak hierdie organiese eenheid : haalbaar. Die NHKA sou nog in 'n organiese eenheid met die Afrikanervolk kan leef, maar beswaarlik met ' $n$ owerheid wat baie min liefde vir die Afrikaner het en in sommige gevalle selfs agnostiese standpunte teenoor die kerk inneem.

Die verbrokkeling van die organiese verhouding tussen kerk en owerheid beteken dat die kerk geen verwagtinge meer van die owerheid kan hê om die Christelike lewenswyse en waardes te beskerm nie. In 'n organiese verhouding tussen kerk en owerheid, luister die owerheid ernstig na die getuienis van die kerk. Daardie verwagting bestaan nie in ' $n$ sekulêre of agnostiese staat nie. Die kerk moet ook daarvolgens beplan en sy bediening struktureer, waar nodig. In der waarheid sou die NHKA, op grond van die owerheid se gelykstelling van alle godsdienste in Suid-Afrika, die vorming van 'n agnostiese staat kon teenstaan, sowel as die gelykheid van godsdienste, die verontagsaming van Christelike beginsels en die miskenning van God se Woord.

Volgens Beza is die miskenning van die ware Christelike geloof 'n grondige rede vir verset, en word verset deel van die christen se heilige plig. Die vraag is hoe? Daar is verskeie vorme van verset, en die belangrikste hiervan is die profetiese getuienis (skriftelik, prediking en so meer) wat die kerk teenoor die volk en die owerheid lewer. Die Algemene Kerkvergadering van die Nederduitsch Hervormde Kerk het in 1995 sterk uitsprake gemaak teen geweldadige verset (AKV van die NHKA 1995:57), maar tegelykertyd die reg van protes en vreedsame verset erken. Dit is volkome in lyn met cire denke van onder andere Beza wat vereis dat die kerk meer gehoorsaam aan God as aan die owerheid moet wees.

Die kerk staan dus derdens ook in 'n profetiese verhouding teenoor die owerheid, soos die profeet Natan toe hy koning Dawid gekonfronteer het en gesê het 'Jy is die man', na aanleiding van sy sonde met Batseba (2 Sam 12:7). Die profetiese verhouding impliseer ook dat die kerk sal sê dat ware vryheid, vrede en versoening net in en 
deur Jesus Christus kan plaasvind, en in verhouding met God gestalte kry. Die beste politieke diens wat die kerk aan die owerheid en die volk kan bewys, is om profeties die evangelie van Jesus Christus te verkondig (Van Niftrik 1950:32).

Die kerk staan vierdens ook in 'n priesterlike verhouding met die owerheid. Dit bestaan daarin dat dit die priesterlike amp van die kerk is om vir die owerheid (en volk) voorbidding te doen. Die opdrag tot voorbidding is baie duidelik in die Skrif - en dit geld afgesien van wie die owerheid is. Die individuele lidmate van die kerk het ook 'n priesterlike amp en roeping (Luther), om op elke lewensterrein te getuig van Jesus Christus, die gekruisigde en opgestane Heer. So word die Christenmens die lig vir die wêreld en die sout vir die aarde. Die kerk is immers nie net sinodale rade en vergaderings wat profeties/priesterlik getuig nie, maar die kerk is in die eerste plek die lidmate wat ook met hulle roeping, as priesters, die wêreld daagliks betree.

Die kerk staan ook in 'n koninklike verhouding met die owerheid. Dit impliseer dat die kerk met vryheid van gewete (Heidelbergse Kategismus Sondag 12/32) die stryd teen die bose en die sonde mag stry. Die kerk moet met die swaard van die Gees, dit is die Woord, die wêreld betree. Die kerk proklameer ook Christus se heerskappy, nie net oor die kerk nie, maar oor die ganse kosmos. Christus is die Heerser van die heersers, die Koning van die konings. Die wet van God is van belang vir die owerheid, al erken hulle dit nie. Christus is ook Koning oor die wêreld (Van Ruler 1945).

Die kerk erken net een gesag en net een Koning, en dit is Jesus Christus. Hoewel die kerk die owerheid se gesag erken om oor die wêreld te regeer, word die kerk deur Jesus Christus, deur sy Woord en Gees, regeer. Wat die kerk betref, het die oweheid net beperkte gesag, en is die kerk vry van owerheid inmenging en oorheersing. Die kerk is nooit die owerheid ten dienste nie, maar alleen sy enigste Koning, Jesus Christus. Hierdie koninklike vryheid teenoor die owerheid, sal die kerk ten alle koste moet bewaar, anders word die kerk die owerheid se lakei. Dat dit 'n wesenlike gevaar is, is oor en oor in die Suid-Afrikaanse geskiedenis bewys. Dit word ook bevestig in die huidige tydsgewrig.

\section{SLOT}

Wanneer die NHKA oor fundamentele sake in die Suid-Afrikaanse politiek besin, moet die Woord en die NHKA se Reformatoriese paradigma as vertrekpunt dien. Anders as wat dikwels gemeen word, sit daar 'n enorme hoeveelheid aktualiteit in die sestiendeeeuse politieke denke van die vadere. Inderdaad was dit hoofsaaklik Calvinistiese denke wat deur die eeue volke in hulle stryd om politieke geregtigheid gehelp het.

Die NHKA moet altyd die spanning tussen kerk, volk en owerheid handhaaf. Tog besef die kerk dat hoewel hy nie van die wêreld is nie, hy in die wêreld is en binne 'n bepaalde konkrete situasie sy opdrag (die verkondiging van die evangelie) moet uitvoer. 
Die kerk besef ook dat as hy bely dat Christus die Kurios is, dit ook bepaalde politieke implikasies het. Die evangelie is van politieke belang. Die Woord van God het iets te sê oor die alledaagse bestaan van mense. Daarvan moet die kerk teenoor owerheid en volk getuig. Die kerk besef ook dat terwyl die aardse owerhede verganklik en tydelik is, God se koninkryk vir ewig duur. Die kerk sal alle owerhede en volke van hierdie wêreld oorleef. Dit is nie net 'n geloofsuitspraak nie, maar ook 'n historiese feit.

\section{Literatuurverwysings}

À Brakel, W 1736. Redelyke godsdienst, Deel 1. Rotterdam: Wed.H van den Aak.

Al'en, J W 1961. A history of political thought in the sixteenth century. London: Methuen.

Augustinus, A 427. De civitate Dei, in The basic writings of St. Augustine. New York: Random House.

Baird, H M 1970. Theodore Beza. New York: Burt Franklin.

Bakhuizen v d Brink, J N 1940. De Nederlandsche Belijdenisschriften Vergelijkende Teksten. Amsterdam: Uitgeversmaatschappij Holland.

$\longrightarrow$ 1980. Handboek der Kerkgeschiedenis, deel 3. Leeuwarden: De Tille BV.

Barth, K 1935. De Apostolische Geloofsbelijdenis. Lesings verwerk deur K H Miskotte. NijKerk: G F Callenbach Uitgever.

1954. Against the stream. London.

Beza, T [1574] (1956). De iure magistratuum in subitos, et officio subitorum erga magistratus, vertaal deur H L Gonin, onder redakteurskap van A H Murray, Cape Town/Pretoria: HAUM.

Bodlaender, M L 1959. Politeia: Grote mannen over staat en maatschappij. Amsterdam: Elsevier.

Bosman, H L (red) 1987. Die Nederlandse Geloofsbelydenis: Ontstaan, Skrifgebruik en gebruik. Pretoria: Unisa.

Botha, S J 1996. Die Corpus Christianum gedurende die Middeleeue. HTS 52/4.

Breytenbach, A P B 1996. Die gebruik van die Ou Testament in die begronding van die Kerk se kultuurtaak: 'n Hermeneutiese probleem. HTS 52/4.

Brutus, J [1579] (1972). Vindiciae contra tyrannos, translated by H J Laski. New York: Burt Franklin.

Buys, F 1980. Die verhouding tussen kerk en staat by Calvyn in kerkhistoriese perspektief. Studiae historiae ecclesiasticae VI.

Caldwell, E C et al 1966. The ancient world. Derde uitgawe. Hinsdale: The Dryden Press.

Calvyn, J [1559] (1949). Institutio christianae religionis, vertaal deur A Sizoo. Tweede uitgawe 1949. Delft: Naamloze Vennootschap W D Meinema. 
De Visser, J Th 1926. Kerk en staat, deel 2. Leiden: AW Sijthoff's Uitgeversmaatschappij.

De Vos, H 1975. Inleiding tot de Wijsbegeerte. NijKerk: Uitgeverij G F Callenbach N V

Deist, F 1975. Die noodlottige band: Die verhouding tussen kerk en staat in OudIsrael. Kaapstad: Tafelberg.

Dreyer, P S 1987. Die voor-Platonise staatsbeskouings, in Faure, A M (red), Die Westerse politieke tradisie. Tweede uitgawe. Pretoria: Academica.

Dreyer, W A 1995. Kerk, volk en owerheid: 'n Hervormde perspektief. DD-proefskrif, Universiteit van Pretoria.

Faure, A M (red) 1987. Die Westerse politieke tradisie. Pretoria: Academica.

Engelbrecnt, S P 1953. Geskiedenis van die Nederduitsch Hervormde Kerk van Afrika. Derde uitgawe. Kaapstad-Pretoria: HAUM.

Fiore, S 1965. Voices from the clay. Norman: University of Oaklahoma Press.

Haitjema, Th L 1957. Calvijn en de Calvinisme, in Waterink, J (red), Cultuurgeschiedenis van het Christendom,1132-1175. Amsterdam/Brussel: Elsevier.

- 1964. De nieuwere geschiedenis van Neerlands Kerk der Hervorming. 's-Gravenhage: Boekencentrum n.v.

Kooiman, W J 1957. Luther, in Waterink, J (red), Cultuurgeschiedenis van het Christendom, 1104-1131. Amsterdam/Brussel: Elsevier.

Koopmans, J 1939. De Nederlandse Geloofsbelijdenis. Amsterdam: Uitgeversmaatschappij Holland.

Krüger, D W 1963. Paul Kruger, deel l, 1803-1904. Johannesburg: Afrikaanse Pers Boekhandel.

Kuyper, A 1937. Briefwisseling van Mr. Groen van Pinsterer met Dr. A. Kuyper 18641870. Kampen: Goslinga.

Louw, J P.(red) 1988. Greek-English lexicon of the New Testament. Goodwood: National Bookprinters.

Luther, M 1523 (1955). Von Weltliche Obrigkeit, herdruk in Steck, K G (red), Luther, 141-170. Frankfurt: Fischer Bucherei.

Mans, C J 1962. Die owerheid in die Nuwe Testament en by die Reformatore. HTS $18 / 3,90-115$.

McNeill, J T 1967. The history and character of Calvinism. New York: Oxford University Press.

Milner, B C 1970. Calvins doctrine of the church. Leiden: Brill.

Miskotte, K H 1935. Aantekeningen, in Barth, K, De Apostolische Geloofsbelijdenis 214-369. Nijkerk: G F Callenbach Uitgever. 
Murray, A H (red) 1956. Theodore Beza. Cape Town/Pretoria: HAUM.

— 1962. The political philosophy of J A De Mist. Cape Town/Pretoria: HAUM.

- 1987. Inleiding, in Faure, A M, Die Westerse politieke tradisie. Pretoria: Academica.

Ned Hervormde Kerk van Afrika 1853/1857. Notulen. S P Engelbrecht versameling. Pretoria:Kerkargieg NHKA.

1862. Notule van die Kommissie van die Algemene Kerkvergadering. Pretoria: Argief NHKA.

- 1995. Besluitebundel. Besluite van die 64ste Algemene Kerkvergadering. Ongepubliseerd.

Pont, A D 1986. Verbond en volkskerk. HTS 42/1, 28-76.

1991. Die verhouding 'kerk en volk' in die jare 1835-1900 in die Oorvaalse:

'n Terreinverkenning. HTS 47/3, 783-799.

Sabine, G H 195: A history of political theory. London: George G. Harrap \& Co.

Saggs, H W F 1962. The greatness that was Babylon. London: Sidgwick and Johnson.

Torrance, J B 1990. The concept of federal theology: Was Calvin a federal theologian? Referaat gehou voor die Calvynkongres, Grand Rapids 1990.

Van Aarde, A G 1996. Kultuurkritiek, eerste-eeuse kulturele wysheid en die alternatiewe visie van Jesus van Nasaret. HTS 52/4, 838-849.

Van der Westhuyzen, H G 1981. Volkskerk en sending. Pretoria: HAUM.

Van Niftrik, G C 1950. Geloof en politiek. Kerk en Theologie 1/1.

Van Ruler, A A 1945. Religie en politiek. NijKerk.

Van Schelven, A A 1956. Introduction, in A A Murray (red), Theodore Beza. Cape Town/Pretoria: HAUM.

Versfeld, M 1987. Aurelius Augustinus, in Faure, A M (red), Die Westerse politieke tradisie. Pretoria-Kaapstad: Academica.

Villa-Vincecio, C 1986. Between Christ and Caesar: Classic and contemporary texts on church and state. Cape Town: Phillip.

Volksraad van die Zuid-Afrikaansche Republiek 1858. Notules. SA Argiefstukke Transvaal no. 3. Staatsdrukker.

Von Hippel, E 1958. Geschichte der Staatsphilosophie. Meisenheim am Glan: Verlag Anton Hain.

Waterink, J (red) 1957. Inleiding over het beorip 'cultuur', in Waterink, J (red), Cultuur-gechiedenis van het Christendom. Amsterdam: Elsevier. 